\title{
Efecto de surfactantes sintéticos, salinidad y alcalinidad sobre las propiedades de las emulsiones asfálticas para impermeabilización
}

\section{Effect of synthetic surfactants, salinity and alkalinity on the properties of asphalt emulsions}

\author{
G. Márquez ${ }^{(*)}$, J. J. Martín $(* *)$, F. J. Alejandre(**), J. C. Fortes ${ }^{(*)}$, F. Prat ${ }^{(*)}$, J. M. Dávila(*)
}

Recepción/Received: 13-VI-07

Aceptación/Accepted: 9-I-08

Publicado online/Online publishing: 27-VII-09

RESUMEN

Este trabajo estudia la influencia de las variables salinidad, alcalinidad y cantidad de surfactantes sintéticos, tanto iónicos como no iónicos, existentes en el emulsivo acuoso empleado para formular emulsiones asfálticas, con vistas a la aplicación de las mismas como recubrimientos impermeabilizantes en edificaciones. Para la preparación de los sistemas emulsionados objeto de estudio, se utilizó como producto bituminoso un crudo extrapesado procedente de Venezuela. En tal sentido, los resultados obtenidos muestran cómo las cuatro variables de formulación anteriormente mencionadas modifican una serie de propiedades físicas (viscosidad, tensión superficial y diámetro promedio de partícula) muy determinantes para la estabilidad de las referidas emulsiones asfálticas.

Palabras clave: emulsiones asfálticas, impermeabilidad, pH, reología, distribución de tamaño de partículas.
SUMMARY

This paper studies the effect of salinity, alkalinity and amount of ionic and non-ionic synthetic surfactants in the aqueous emulsifier used to prepare oil-in-water or asphaltic emulsions on the performance of such substances as waterproofing on buildings. The emulsion systems studied here were prepared with Venezuelan extra heavy oil. The findings showed that the four variables modified viscosity, surface tension and mean particle size, physical properties that are instrumental to asphalt emulsion stability.

Keywords: asphalt emulsions, impermeability, $p H$, rheology, particle size distribution.
(*) Universidad de Huelva (Huelva, España).

(**) Universidad de Sevilla (Sevilla, España).

Persona de contacto/Corresponding author: jjdelrio@us.es 


\section{INTRODUCCIÓN}

La Norma Básica de la Edificación QB-90 (1), a sustituir en un futuro por la NBE-IQ "Impermeabilización de Cubiertas", estableció las condiciones exigibles a las cubiertas de obras de construcción de edificios de nueva planta, de ampliación y de reforma que se realicen con materiales bituminosos. En esta norma de carácter obligatorio hasta 29 de marzo de 2007, fecha en que se derogó por el Documento Básico HS-1 del Código Técnico de la Edificación, las emulsiones asfálticas son, junto con las pinturas bituminosas, productos líquidos utilizados para la imprimación y la preparación de las distintas superficies que vayan a impermeabilizarse con el fin de mejorar la adherencia del material impermeabilizante con el soporte.

Las emulsiones asfálticas, designadas con la sigla E seguida de un guión, de la letra indicativa al tipo de emulsión ( $A, B, C$ ó D) y de la respectiva referencia (2), son aplicadas en capa fina, que al secarse forma una película sólida continua, mediante brocha, cepillo o pulverizador. Su misión consiste en entrar en contacto con la superficie del soporte para aumentar su adherencia y conseguir autoprotección (3).

Se trata, pues, de un material de suma importancia para el sector de la construcción por sus propiedades de consistencia, impermeabilidad y durabilidad (4). Aunque dichas emulsiones asfálticas se obtienen por dispersión de betunes asfálticos, obtenidos de la destilación de determinados crudos de petróleo, en agua o en una solución acuosa con un surfactante o emulsionante; es posible usar directamente los petróleos asfálticos que cumplan con unas especificaciones determinadas. En tal sentido, parte del asfalto líquido que se utiliza, desde épocas pasadas, es el crudo bituminoso; el cual se encuentra en yacimientos naturales y pueden explotarse sin necesidad de operaciones industriales de ningún tipo para su preparación. Estos yacimientos, los más importantes se localizan en Venezuela y Estados Unidos (5), se han producido por un proceso natural de evaporación de las fracciones volátiles del petróleo, enriqueciendo las pesadas.

Las emulsiones asfálticas pueden definirse como un sistema, termodinámicamente inestable, constituido por dos fases líquidas, una orgánica (crudo extrapesado en este caso) y otra acuosa, una de las cuales se encuentra dispersada en la otra, en forma de glóbulos o partículas mayores de 0,4 $\mu \mathrm{m}$, y cuya estructura se estabiliza por la presencia obligada de uno o varios surfactantes 0 compuestos tensoactivos. Asimismo, los surfactantes se caracterizan por una estructura molecular que incluye dos grupos que difieren ampliamente en sus relaciones de solubilidad; un grupo polar que es afín a medios acuosos, y otro apolar que presenta afinidad por medios

\section{INTRODUCTION}

Basic Building Code QB-90 (1), later superseded by NBE10 "Roof waterproofing", laid down the requirements for all roofs containing bituminous materials, whether built over new or refurbished buildings or additions. This statutory code, which was in effect until 29 March 2007 when it was superseded by Technical Building Code Basic Document HS-1, defined asphalt emulsions, together with bituminous paint, to be products used to prime and prepare surfaces for waterproofing by improving the bonding between the water-repellent substance and the substrate.

Asphalt emulsions, which are designated by the letter $E$ followed by a dash, the letter $(A, B, C$ or $D)$ indicating the emulsion type, and the respective reference (2), can be brushed or sprayed onto the substrate as a thin coat that, when dry, forms a continuous solid film. The purpose of this film is to bind to the underlying surface to enhance bonding and self-protection (3).

It is, then, a material of cardinal importance for the construction industry for its consistency, bonding strength, water-tightness and durability (4). These asphalt emulsions are normally obtained by mixing semisolid asphalt tar, produced by distilling certain types of oil, in water or an aqueous solution with a surfactant or emulsifier. Nonetheless, when they meet a series of requisites certain types of asphalt oil can be used directly. In fact, bituminous oil found in natural deposits has long been used as liquid asphalt with no need for any manner of industrial processing or preparation whatsoever. Such deposits, the largest of which are located in Venezuela and the United States (5), are formed by natural evaporation of the more volatile fractions of oil, and the concomitant thickening of the heavier fractions.

Asphalt emulsions can be defined to be a thermodynamically unstable system comprising two liquid phases, one organic (extra heavy oil in this case) and the other aqueous, in which the former is dispersed in the latter in the form of droplets or particles over $0.4 \mu \mathrm{m}$ in diameter. System structure is stabilized by the necessary presence of one or several surface-active agents, a term shortened in the nineteen fifties to "surfactant". The molecular structure of these compounds characteristically consists in two groups whose solubility differs widely: a hydrophilic or polar group and a hydrophobic or non-polar group (6). 
orgánicos (6). Químicamente, pueden clasificarse como iónicos, no iónicos y anfotéricos (7). Estos últimos casi no se usan debido a su elevado costo.

La presencia de surfactantes naturales (aquéllos que son componentes intrínsecos de un emulsivo) en crudos extrapesados es bien conocida (8), así como el papel de tales compuestos tensoactivos en la formación y estabilización de emulsiones asfálticas (9). Los componentes del crudo de petróleo que son compuestos tensoactivos han sido identificados como ácidos carboxílicos, resinas y asfaltenos (10). Los ácidos carboxílicos presentes en petróleos extrapesados (ácidos mirístico $\left[\mathrm{C}_{14} \mathrm{H}_{28} \mathrm{O}_{2}\right]$, palmítico $\left[\mathrm{C}_{16} \mathrm{H}_{32} \mathrm{O}_{2}\right]$ y esteárico $\left(\mathrm{C}_{18} \mathrm{H}_{36} \mathrm{O}_{2}\right)$, entre otros) sufren un proceso de saponificación en presencia de una base o cosurfactante, por ejemplo monoetanolamina [ $\left.\mathrm{C}_{2} \mathrm{H}_{7} \mathrm{NO}\right]$, que se evidencia por un descenso de la tensión interfacial (11).

La estabilidad de las emulsiones asfálticas para impermeabilizaciones viene referida, en términos generales, a la ausencia de variación en propiedades como el diámetro promedio de partícula o la viscosidad, en un periodo de tiempo suficiente para el propósito de una aplicación práctica específica. Al tal respecto, la estabilidad de una emulsión decrece a mayor valor promedio y desviación típica del diámetro de partícula (12); así como a las interacciones entre los glóbulos dispersos en la fase continua, durante las colisiones entre ellos, consecuencia del movimiento browniano. Estas interacciones son de dos tipos: atractivas o de Van der Waals y repulsivas. Cuando la atracción prevalece sobre la repulsión, los glóbulos se adhieren y la emulsión muestra floculación y/o coalescencia; en caso contrario, la emulsión permanece estable en estado disperso (13). Las fuerzas repulsivas en emulsiones son de origen electrostático cuando se utilizan surfactantes iónicos, debido a la repulsión entre las dobles capas eléctricas que rodean los glóbulos dispersos (14); o de origen estérico, consecuencia de la repulsión entre capas monomoleculares de surfactantes no iónicos adsorbidas sobre la superficie de los glóbulos o partículas (15).

Además, existen datos (16) que indican la influencia ejercida por las características fisicoquímicas del emulsivo acuoso mezclado con un crudo extrapesado, sobre la viscosidad, la tensión superficial y el tamaño promedio de partícula de las correspondientes emulsiones asfálticas; siendo tales características unos factores claves para la estabilidad de los citados sistemas durante su transporte, manejo, almacenamiento y aplicación.

En definitiva, el objetivo del trabajo es investigar los efectos ejercidos por los diferentes niveles de salinidad, alcalinidad y surfactantes sintéticos, iónicos y no iónicos, sobre emulsiones de crudo extrapesado en emulsivos acuosos con monoetanolamina como cosurfactante, a fin de conocer cómo influyen el $\mathrm{pH}$, la fuerza iónica de la
Chemically, they can be classified as ionic, non-ionic or zwitterionic or amphoteric (7), although the third type is costly and for that reason seldom used.

Natural surfactants, the intrinsic components in an emulsifier, are known to exist in extra heavy oil (8), and the role of such surface active compounds in the formation and stabilization of asphalt emulsifiers is well understood (9). The surface active compounds in oil have been identified to be carboxylic acids, resins and asphaltenes (10). In the presence of a base or cosurfactant such as monoethanolamine $\left(\mathrm{C}_{2} \mathrm{H}_{7} \mathrm{NO}\right)$, the carboxylic acids present in extra heavy oil (i.e., myristic $\left(\mathrm{C}_{14} \mathrm{H}_{28} \mathrm{O}_{2}\right)$, palmitic $\left(\mathrm{C}_{16} \mathrm{H}_{32} \mathrm{O}_{2}\right)$ and stearic $\left(\mathrm{C}_{18} \mathrm{H}_{36} \mathrm{O}_{2}\right)$ acids, among others) are saponified, lowering interfacial tension (11).

Asphalt emulsion stability is defined, generally speaking, as the absence of variations in properties such as mean particle size and viscosity over a long enough time to fulfil a specific practical use. In this respect, emulsion stability declines with rising mean particle size and standard deviation values (12), as well as with the intensity of the interactions among the droplets dispersed in the continuous phase that collide as a result of Brownian movement. These interactions may be of one of two types: attractive, also known as van der Waals, or repulsive forces. When attraction prevails over repulsion, the droplets adhere to one another and the emulsion flocculates or coalesces; otherwise, it remains stable and disperse (13). The repulsive forces in emulsions are electrostatic when ionic surfactants are used, due to the double layer of electrons that surround the disperse droplets (14), or steric in the presence of non-ionic agents, as a result of the repulsion among the monomolecular layers of surfactant adsorbed on the surface of the droplets or particles (15).

Furthermore, data have been reported (16) that show that the physical-chemical characteristics of the aqueous emulsifier affect viscosity, surface tension and the mean particle size of asphalt emulsions. Such characteristics are key factors in system stability during shipping, handling, storage and use.

The purpose of the present paper is to explore the effects of aqueous emulsifier salinity and alkalinity, and ionic and non-ionic synthetic surfactants, on extra heavy oil emulsions in which the cosurfactant is monoethanolamine. More specifically, it studies the impact of $\mathrm{pH}$, the ionic force of the aqueous phase and 
fase acuosa o la presencia de ciertos compuestos tensoactivos en las condiciones finales, especialmente la viscosidad y el diámetro promedio de partícula, de las referidas emulsiones.

Los resultados obtenidos contribuyen a sentar las bases para obtener una nueva generación de emulsiones asfálticas para impermeabilización, con mejores propiedades, como consecuencia del uso de nuevos surfactantes sintéticos que muestren un efecto sinérgico positivo sobre los surfactantes naturales presentes en productos bituminosos; posibilitando así una adecuada comprensión del modo en que deben formularse y formarse las emulsiones asfálticas para obtener un mayor rendimiento final en los recubrimientos impermeabilizantes.

\section{PARTE EXPERIMENTAL. METODOLOGÍA}

Para la preparación de cada emulsión asfáltica se pesó una cantidad de crudo bituminoso (375 g), proveniente de la planta MPE-1 (Morichal, Venezuela) para colocarlo durante 2 horas en un baño termostatizado a $65^{\circ} \mathrm{C}$. Previamente se produjo el secado de dicho crudo, tras disolverlo en exceso de tolueno, mediante destilación hasta eliminar toda la mezcla azeotrópica de agua y disolvente a $78^{\circ} \mathrm{C}$. Asimismo, el aditivo (hidróxido sódico, halita o surfactante sintético) era añadido a $250 \mathrm{ml}$ de disolución al 1,5\% de monoetanolamina en agua destilada. La presencia de monoetanolamina en la fase acuosa permite la activación de los surfactantes naturales presentes en el crudo extrapesado. A posteriori, se mezclan ambas fases en un emulsor, agitando a 200 rpm durante 2 minutos, para luego continuar el proceso de mezcla durante otros 2 minutos a $1.220 \mathrm{rpm}$. Finalmente, se va añadiendo agua destilada hasta alcanzar aproximadamente una proporción del $40 \%$ de fase acuosa.

Se ha operado a diferentes concentraciones (200, 700 y 1.500 ppm) de hidróxido sódico, halita y de cada de las mezclas de surfactantes sintéticos, para efectuar un estudio comparativo a $25^{\circ} \mathrm{C}$ de la viscosidad, la tensión interfacial y el diámetro promedio de partícula en los sistemas emulsionados obtenidos. En concreto, se utilizaron cuatro surfactantes sintéticos para la preparación de las emulsiones asfálticas objeto de estudio, todos ellos con un parámetro característico de Griffin (HLB) superior a 11, dos no iónicos - tridecanol etoxilado y alquilpoliglucósido- mezclados en proporción 1:1, y otros dos iónicos (ácido linoleico y ácido adípico) mezclados en proporción 2:1.

Las emulsiones preparadas fueron almacenadas durante dos meses a fin de medir periódicamente la viscosidad y el diámetro promedio de partícula. Además, las tensiones interfaciales se obtuvieron a los 7 días, añadiendo the presence of certain surface active compounds on the final characteristics of such emulsions, especially viscosity and mean particle size.

The findings will contribute to establishing the basis for a new generation of asphalt emulsions with better weatherproofing properties resulting from the use of new synthetic surfactants that exhibit synergies with the natural surfactants present in bituminous products. They will also provide a full understanding on how asphalt emulsions should be formulated and manufactured to ensure the best performance of weatherproof coatings.

\section{EXPERIMENTAL. METHODOLOGY}

To prepare the asphalt emulsions, $375 \mathrm{~g}$ of bituminous oil from plant MPE-1 (Morichal, Venezuela) were immersed in a thermostatic bath at $65^{\circ} \mathrm{C}$ for two hours. The oil had been previously dissolved in excess toluene and distillation-dried at $78{ }^{\circ} \mathrm{C}$ until the azeotropic mixture of water and solvent had been eliminated entirely. The additives, sodium hydroxide, halite or synthetic surfactant, were added to $250 \mathrm{ml}$ of a $1.5 \%$ monoethanolamine solution (in distilled water). The presence of monoethanolamine in the aqueous phase activates the natural surfactants present in the extra heavy oil. The two phases were subsequently mixed and stirred at $200 \mathrm{rpm}$ for two minutes and then for a further two minutes at $1220 \mathrm{rpm}$. Finally, distilled water was added to raise the proportion of aqueous phase to approximately $40 \%$.

Different concentrations (200, 700 and 1500 ppm) of sodium hydroxide, halite and each synthetic surfactant were used to conduct a comparative study, at $25^{\circ} \mathrm{C}$, of viscosity, interfacial tension and the mean particle size in the systems prepared. Four synthetic surfactants were used to prepare the asphalt emulsions studied, all with Griffin HLB values of over 11: the two non-ionic substances (ethoxylated tridecanol and alkylpolyglucoside) were mixed in a proportion of $1: 1$ and the two ionic compounds (linoleic and adipic acids) in a proportion of $2: 1$.

The emulsions were stored for two months, during which time the viscosity and mean particle size were periodically measured. Seven-day interfacial tension readings were also taken, for which purpose the extra 
xileno a cada emulsión y homogeneizando durante 1 minuto, con el propósito de diluir el crudo extrapesado y reducir la densidad antes de medir.

Para el desarrollo experimental de este trabajo, se emplearon los equipos que se describen a continuación: un mezclador S-ST marca Myers; un viscosímetro de cilindros concéntricos Haake modelo RV-20, equipado con un reocontrolador RC-20 y un sistema sensor MV-1; así como un tensiómetro SITE-100 para determinar la tensión interfacial en cada uno de los sistemas emulsionados mediante el método Spinning-drop. Adicionalmente, el equipo empleado para medir el diámetro promedio de partícula fue un Mastersizer-E marca Malvern, siguiendo el método normalizado establecido por la Norma Internacional ISO 13320-1 (17). Por último, la densidad o gravedad API del crudo extrapesado se determinó, según norma ASTM D-2041 (18), utilizando un dispositivo Rice que incluía un conjunto de elementos necesarios: vibrador, picnómetro de vacío, bomba de vacío, juego de filtración, balanza electrónica y un manómetro de presión residual.

\section{RESULTADOS Y DISCUSIÓN}

Como ya se ha señalado anteriormente, una propiedad importante del crudo utilizado es su elevada densidad (gravedad API igual a $8,1^{\circ}$ ), valor relacionado con su alto contenido en surfactantes naturales.

Comenzando la discusión de los resultados obtenidos en relación a la denominada emulsión asfáltica base, es decir, aquella formulada únicamente a partir de crudo extrapesado, agua destilada y monoetanolamina, los datos obtenidos muestran que la viscosidad aumenta ligeramente con el tiempo (figuras 1b, 2b, 3b ó 4b), lo cual evidencia un leve grado de floculación del sistema, proceso por el cual las partículas se aglomeran para formar disposiciones complejas. De igual modo, el aumento poco significativo del diámetro medio de partícula (figuras 1a, 2a, 3a ó 4a) no indica coalescencia, lo cual supondría el drenaje de la película de fase acuosa entre dos glóbulos adyacentes hasta su ruptura (9).

Por otra parte, y una vez analizados los sistemas emulsionados con diferentes cantidades de $\mathrm{NaCl}$ añadidas al emulsivo acuoso, en concentraciones entre 200 y 1.500 ppm, con el fin de determinar el efecto de un electrolito fuerte sobre las propiedades de tales emulsiones asfálticas, se observa que el diámetro promedio de partícula (Figura 1a) y la tensión interfacial (Figura 5) decrecen al aumentar la fuerza iónica de la fase acuosa. Ello puede atribuirse a que electrolitos fuertes disueltos en la fase acuosa, caso de la halita, provocan una mayor concentración de moléculas de surfactantes naturales adsorbidas en heavy oil was diluted to lower its density by adding xylene to each emulsion and homogenizing the mix for one minute.

The equipment described below was used for the experimental part of this study: a Myers S-ST dispersion mixer; a Haake RV-20 concentric cylinder viscometer fitted with an RC-20 rheocontroller and an MV-1 sensor; a SITE-100 tensiometer to determine emulsion interfacial tension using the spinning drop method. In addition, the mean particle size was measured with a Malvem Mastersizer- $E$ instrument in accordance with the procedure set out in international standard ISO 13320-1 (17). Lastly, the API density or gravity of the extra heavy oil was determined as described in American standard ASTM D-2041 (18) with a Rice testing device fitted with all the necessary elements: vibrator, vacuum pycnometer, vacuum pump, full set of filters, electronic scales and a residual pressure manometer.

\section{RESULTS AND DISCUSSION}

As specified above, one of the most important properties of crude oil is its high density (API gravity, 8.10), which is related to its high natural surfactant content.

According to the findings for the standard or control asphalt emulsion, i.e., the mix consisting solely of extra heavy oil, distilled water and monoethanolamine, viscosity rose slightly over time (Figures $1 b, 2 b, 3 b$ an $4 b)$, denoting slight system flocculation, in which the particles aggregate in complex clusters. Similarly, the scantly significant increase in mean particle size (Figures 1a, 2a, 3a and 4a) indicated no coalescence, which entails drainage of the aqueous phase film between two adjacent droplets and their subsequent rupture (9).

The results for the systems emulsified with concentrations of $\mathrm{NaCl}$ ranging from 200 to 1500 ppm, added to determine the effect of a strong electrolyte on asphalt emulsion properties, showed that the mean particle size diameter (Figure 1a) and interfacial tension (Figure 5) declined with rising ionic force in the aqueous phase. This may be attributed to the higher concentration of natural surfactants adsorbed on the interface, induced by the presence of strong electrolytes, all of which inhibits the salting out effect or desorption of these molecules into the aqueous phase. At the same 
la interfase, inhibiendo la desorción de estas moléculas hacia la fase acuosa (efecto "salting out"); asimismo, los iones sodio pueden interactuar con las citadas moléculas de surfactantes naturales, disminuyendo la repulsión entre ellas en la interfase $y$, como consecuencia, permitiendo que un mayor número de dichas moléculas se adsorban en la interfase (19).

La viscosidad de las emulsiones aditivadas con monoetanolamina y $\mathrm{NaCl}$ se ha visto notablemente aumentada con la mayor concentración de halita en la fase acuosa (Figura 1b), si se compara con la emulsión base. Estos resultados son los que cabía esperar, puesto que las interacciones entre partículas más pequeñas son mayores $y$, por ende, las emulsiones son más viscosas a mayor salinidad. Probablemente, el efecto que predomina en estos sistemas, a diferencia de lo que ocurre al añadir $\mathrm{NaOH}$, es la neutralización de las cargas de las moléculas de surfactantes naturales adsorbidas en la interfase, lo cual facilita la floculación, fenómeno responsable del incremento de la viscosidad (20).

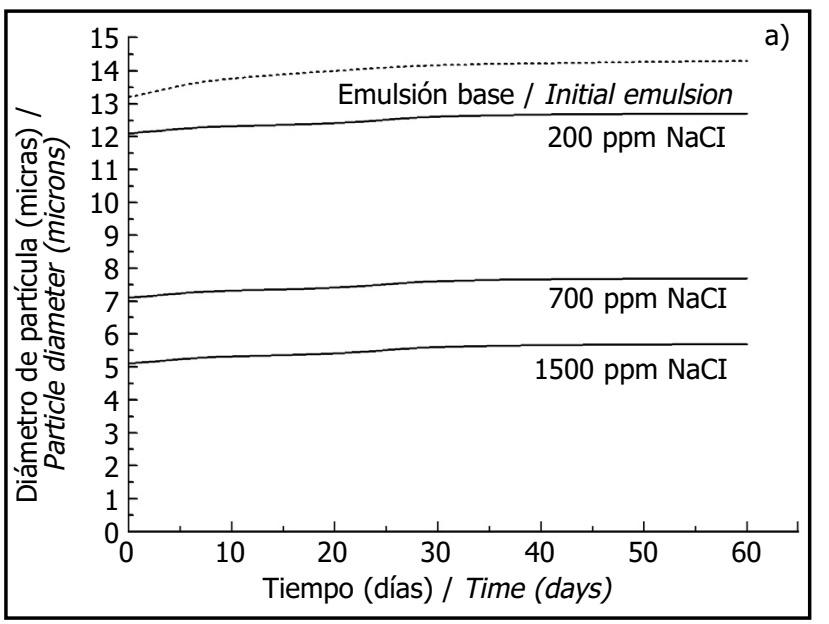

time, the sodium ions may reduce the repulsion between natural surfactant molecules, a higher percentage would therefore be adsorb on the interface (19).

The viscosity of the emulsions containing monoethanolamine and the highest concentration of $\mathrm{NaCl}$ in the aqueous phase was visibly greater (Figure 1b) than in the initial emulsion. This was to be expected, for smaller particles interact more intensively and therefore emulsions with higher salinity are more viscous. The effect that prevails in these systems, by contrast to the result of adding $\mathrm{NaOH}$, is the neutralization of the molecular charge on the natural surfactants adsorbed on the interface, facilitating flocculation, which is in turn responsible for higher viscosity (20).

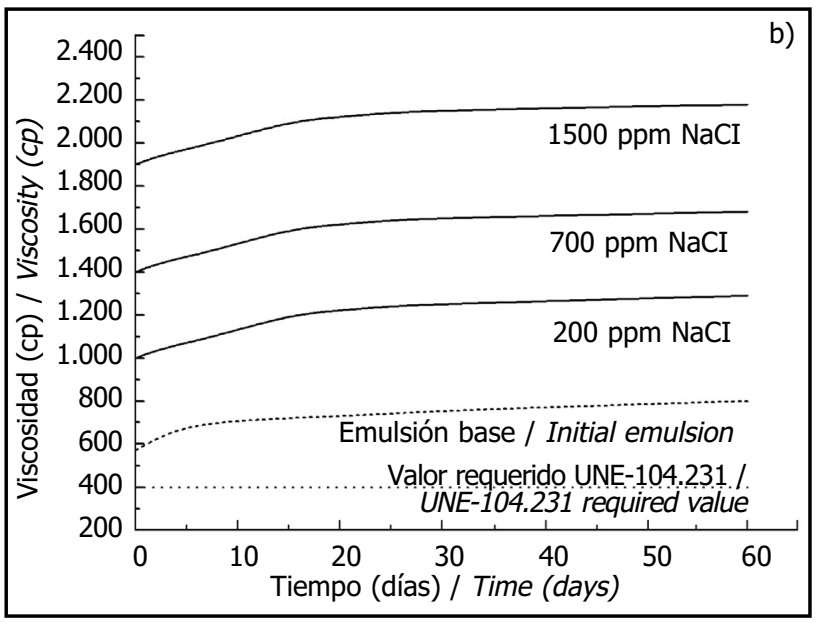

Figura 1. Variación en el tiempo de las emulsiones con $\mathrm{NaCl}$ : a) diámetros promedios de partícula, b) viscosidades.

Figure 1. Variation in $\mathrm{NaCl}$-containing emulsions: a) mean particle size, b) viscosity.

En lo que respecta a las emulsiones aditivadas con $\mathrm{NaOH}$, se observa que el diámetro promedio de partícula disminuye significativamente conforme aumenta el $\mathrm{pH}$ de la fase acuosa (Figura 2a). Asimismo, las viscosidades de todas estas emulsiones fueron menores que la correspondiente a la emulsión base, disminuyendo los valores de dicha propiedad (Figura $2 b$ ) con el crecimiento de la concentración de $\mathrm{NaOH}$ en la fase acuosa. En cuanto a la estabilidad frente a la floculación y/o coalescencia, el comportamiento del diámetro medio de partícula y de la viscosidad en las emulsiones formuladas con hidróxido sódico es similar a la emulsión base, aunque con una tasa de crecimiento aún más pequeña.

El hecho llamativo de que las emulsiones formuladas con monoetanolamina y $\mathrm{NaOH}$ disminuyan su viscosidad a
In the emulsions to which $\mathrm{NaOH}$ was added, the mean particle size declined significantly with rising aqueous phase $\mathrm{pH}$ (Figure 2a). Moreover, all these emulsions had lower viscosity values than the initial emulsion, and the higher the $\mathrm{NaOH}$ concentration in the aqueous phase, the lower the value (Figure 2b). The stability of flocculation and/or coalescence, mean particle size and viscosity values was similar in the sodium hydroxidecontaining and initial emulsions, although the rate of variation was smaller in the former.

The decline in viscosity in emulsions containing monoethanolamine and $\mathrm{NaOH}$ with rising aqueous 
mayor alcalinidad del emulsivo acuoso, a pesar de que el diámetro promedio de partícula sea menor conforme aumenta la concentración de $\mathrm{NaOH}$, se explica por los valores muy bajos de tensión superficial que presentan estos sistemas (Figura 5). En las emulsiones con muy baja tensión superficial las partículas dispersas se deforman fácilmente, alineándose con las líneas de flujo, observándose valores bajos de viscosidad en tales casos (21). emulsifier alkalinity is striking because the mean particle size is lower at higher concentrations of $\mathrm{NaOH}$. The explanation lies in the very low surface tension values found in these systems (Figure 5). In emulsions with very low surface tension, the disperse particles are readily deformed and align along the flow lines, all of which leads to low viscosity (21).
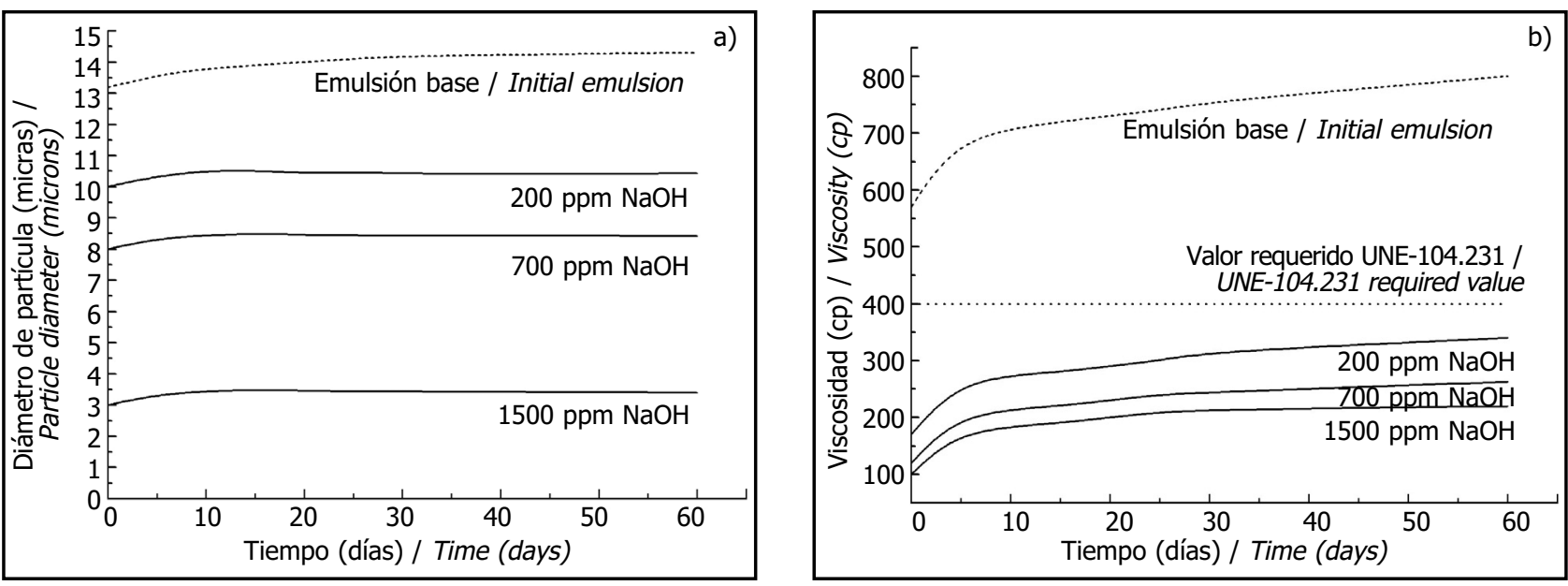

Figura 2. Evolución con el tiempo de las emulsiones con $\mathrm{NaOH}$ : a) tamaño de partícula, b) viscosidades.

Figure 2. Variation in $\mathrm{NaOH}$-containing emulsions: a) mean particle size, b) viscosity.

El carácter básico fuerte del álcali utilizado para activar los surfactantes naturales influye en la concentración de moléculas de éstos en la interfase; puesto que mientras la monoetanolamina sólo es capaz de activar los ácidos más fuertes o de menor peso molecular, el hidróxido sódico activa todos los ácidos orgánicos presentes en el crudo extrapesado, lo cual trae como consecuencia una mayor concentración de moléculas de surfactantes naturales adsorbidas en la interfase (22).

Se formularon diversas emulsiones de manera similar al sistema base, pero añadiendo diferentes cantidades de una mezcla 1:1 de dos surfactantes sintéticos no iónicos, alquilpoliglucósido y tridecanol etoxilado. Los resultados correspondientes al diámetro promedio de partícula para estas emulsiones (Figura 3a) indican que esta propiedad ve ligeramente incrementados sus valores con el aumento de la cantidad de surfactantes no iónicos, a bajas concentraciones de estos aditivos; sin embargo, el tamaño medio de partícula disminuye con el incremento de la concentración de la mezcla de surfactantes no iónicos en el rango de 200 a 1.500 ppm, hasta alcanzar valores inferiores a los de la emulsión base. Asimismo, los datos de viscosidad obtenidos para los sistemas emulsionados con surfactantes no iónicos (Figura $3 b$ ) son similares a las correspondientes a la emulsión base; además, los valores de esta última propiedad crecen regularmente con la cantidad añadida de dichos aditivos y con el tiempo de almacenamiento.
The highly basic nature of the alkali used to activate the natural surfactants induced concentration of these molecules in the interface. Indeed, whereas monoethanolamine can only activate very strong or light molecular weight acids, sodium hydroxide activates all the organic acids present in extra heavy oil. The result was the aforementioned higher concentration of natural surfactants adsorbed on the interface (22).

Further emulsions were prepared as described above for the standard system, but adding different amounts of a 1:1 mix of the two non-ionic synthetic surfactants, alkylpolyglucoside and ethoxylated tridecanol. The mean particle size in these emulsions (Figure 3a) increased slightly with rising amounts of non-ionic surfactant when the additive concentration was low; in the 200 to $1500 \mathrm{ppm}$ range, however, with rising surfactant concentrations, the mean particle size declined to values lower than recorded for the initial emulsion. The viscosity values observed for the systems emulsified with non-ionic surfactants (Figure 3b) were similar to the findings for the initial emulsion. Moreover, these values grew steadily with additive concentration and storage time. 

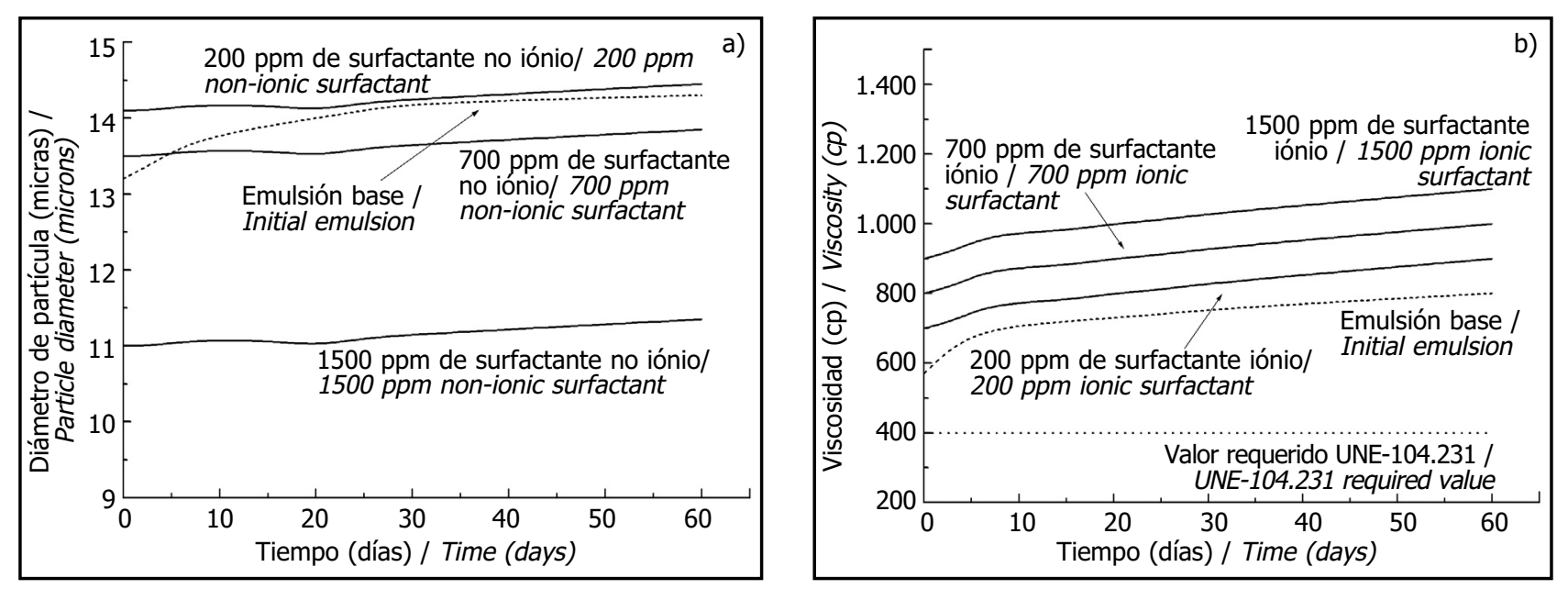

Figura 3. Cambios en sistemas con aditivos no iónicos: a) tamaño de partícula vs. tiempo, b) viscosidad vs. Tiempo. Figure 3. Variation in non-ionic additive-containing emulsions: a) mean particle size, b) viscosity.

Este comportamiento puede atribuirse al hecho de que los surfactantes naturales y los sintéticos no iónicos empleados se adsorben conjuntamente en la interfase, surgiendo un sinergismo positivo entre ambos que origina un descenso del valor de la tensión interfacial (Figura 5) y, por ende, en una ruptura más fácil de las partículas de la fase interna en otras más pequeñas, aumentando las interacciones entre las mismas (8).

Por último, el uso como aditivo de una mezcla 2:1 de dos surfactantes sintéticos iónicos, ácidos linoleico y adípico, en emulsiones de crudo extrapesado en una disolución acuosa de monoetanolamina al 1,5\%, produce unos resultados negativos en cuanto al diámetro promedio de partícula (Figura 4a), pues los valores de esta propiedad se incrementan levemente con el aumento de la cantidad de dichos aditivos, a bajas concentraciones de estos surfactantes; para luego disminuir el tamaño medio de partícula en todo el intervalo de concentración (200 a 1.500 ppm) de dicha mezcla de surfactantes, presentándose
This behaviour can be attributed to the fact that the natural and non-ionic synthetic surfactants were jointly adsorbed on the interface. The origin of these synergies was a decline in interfacial tension (Figure 5) and therefore the readier rupture of internal phase particles into smaller, more intensely interacting droplets (8).

Lastly, the inclusion of a 2:1 mix of two ionic surfactants, linoleic and adipic acids, in extra heavy oil, in a $1.5 \%$ aqueous monoethanolamine solution yielded adverse results in terms of mean particle size (Figure 4a), for the values rose slightly with increasing amounts of additive at low surfactant concentration. Across the entire concentration range of 200 to 1500 ppm, however, the mean particle size declined to values smaller than in the initial emulsion. In addition, the viscosity values were higher than in the initial emulsion (Figure 4b) and rose with rising ionic
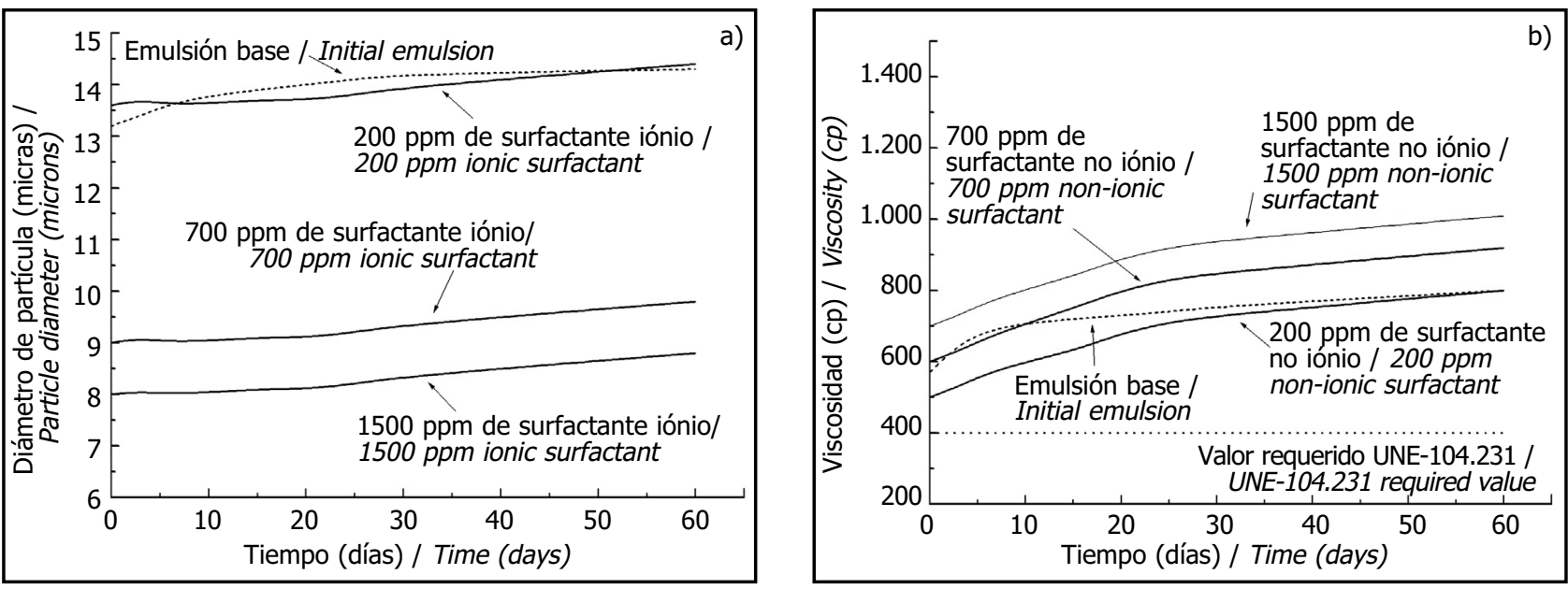

Figura 4. Evolución con el tiempo de sistemas con ácidos adípico y linoleico: a) tamaño de partícula, b) viscosidad. Figure 4. Variation in ionic additive-containing emulsions: a) mean particle size, b) viscosity. 
valores del diámetro promedio de partícula inferiores a los de la emulsión base. Además, se observa unas viscosidades superiores a las de la emulsión base (Figura 4b), así como un aumento del valor de esta propiedad, en todo el intervalo analizado, con el incremento de la concentración de surfactantes sintéticos iónicos.

Es evidente que en estas formulaciones existe, a bajas concentraciones de surfactantes sintéticos iónicos, una sinergia negativa entre éstos y los surfactantes naturales; ello se explica porque la interacción entre estos dos grupos de tensoactivos en la interfase no resulta efectiva, compitiendo ambos por el espacio en ella y disminuyendo, por ende, la concentración de los surfactantes naturales en la misma. No obstante, el tamaño de las partículas pasa a decrecer con aumentos posteriores de la concentración de surfactantes sintéticos iónicos. En estos últimos sistemas, con mayores cantidades de ácido adípico y ácido linoleico, sí parece existir una sinergia positiva entre los dos grupos de surfactantes referidos (8). Por todo lo anterior, los correspondientes valores de la tensión interfacial (Figura 5) son desfavorables, si se comparan con los datos obtenidos para la emulsión base, ya que aquellos superan en todos los casos a estos últimos. synthetic surfactant concentration across the entire interval analyzed.

Quite obviously, negative synergies were generated between ionic synthetic and natural surfactants at low concentrations of the former. The explanation was that the interfacial interaction between these two groups of surface active agents was ineffective, for they competed for space and ultimately lowered the concentration of natural surfactants at the interface. Nonetheless, the particle size declined with subsequent increases in ionic synthetic surfactant concentration. However, synergies did appear to arise between the two groups of surfactants in these latter systems when larger amounts of adipic and linoleic acid were added (8). For all the foregoing, the respective interfacial tension values (Figure 5) were unfavourable compared to the initial emulsion, for the former were higher than the latter in all cases.

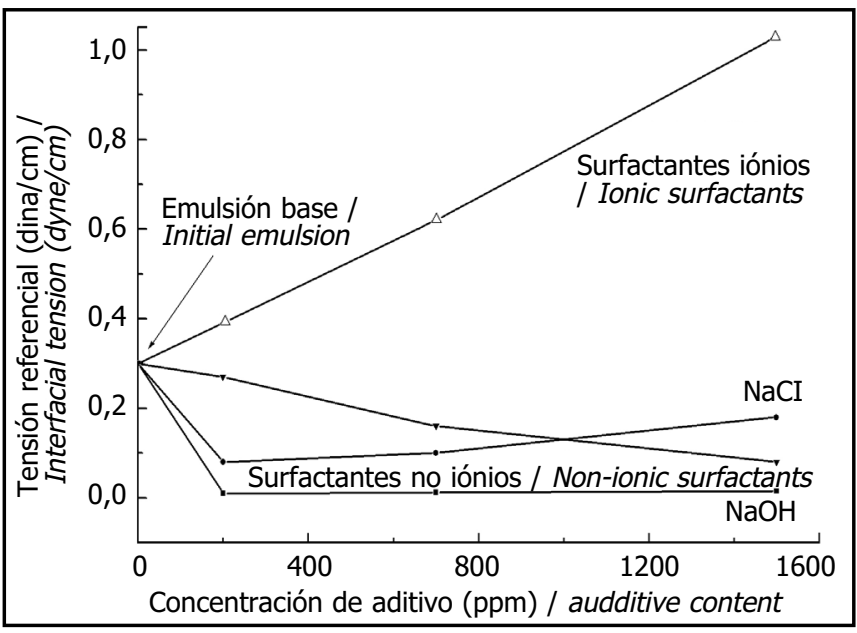

Figura 5. Variación de la tensión interfacial con la concentración de cada aditivo en el emulsivo acuoso. Figure 5. Variation in interfacial tension in emulsions containing additives.

\section{CONCLUSIONES}

Tras realizar el análisis de los resultados obtenidos, procede mencionar una serie de conclusiones:

De acuerdo con la investigación desarrollada, puede establecerse que todas las emulsiones asfálticas estudiadas presentan buenos niveles de estabilidad frente a los fenómenos de coalescencia y/o floculación, pues no se observan incrementos realmente significativos del diámetro promedio de partícula durante el periodo de almacenamiento considerado.

\section{CONCLUSIONS}

The following conclusions can be drawn from an analysis of the findings:

Further to the findings, coalescence and/or flocculation were stable in all the asphalt emulsions, for no material increases in mean particle size were observed during the established storage time. 
La mayoría de los aditivos empleados presentan una sinergia positiva con los surfactantes naturales existentes en el crudo extrapesado; lo cual se manifiesta en valores bajos de la tensión interfacial, debido a una fácil deformación de las partículas durante la formación de la emulsión y su posterior ruptura en partículas o glóbulos más pequeños. Sin embargo, el uso de surfactantes sintéticos iónicos no ha supuesto una sinergia positiva entre los mismos y los citados surfactantes naturales; en este caso, no se observan valores tan bajos de la tensión interfacial, debido a la inefectiva interacción entre ambos grupos de surfactantes en la interfase.

Al hacer referencia al efecto de las formulaciones analizadas sobre la viscosidad, por lo general, excepto en el caso de la adición de $\mathrm{NaOH}$, no fueron muy positivos, ya que se encontraron valores más altos que los correspondientes a la emulsión base, siendo necesario añadir más agua para alcanzar el máximo valor permitido (400 cp) por la norma UNE-104.231; más aún, se observó un aumento de la viscosidad con el tiempo de almacenamiento a mayores salinidad o presencia de surfactantes sintéticos. Asimismo, las emulsiones asfálticas del crudo extrapesado en disolución acuosa de monoetanolamina e hidróxido sódico mostraron, en todo el intervalo considerado, unas viscosidades y unas tensiones interfaciales notablemente bajas. Adicionalmente, y conforme aumenta la alcalinidad, se logra estabilizar más a las emulsiones formuladas.

\section{AGRADECIMIENTOS}

Los autores desean agradecer su colaboración a la compañía INTEVEP S.A.
Most of the additives used generated synergies with the natural surfactants existing in the extra heavy oil, visible in the low interfacial tension values recorded. This, in turn, was a result of the ease with which the particles were deformed during preparation of the emulsion and their subsequent rupture into smaller particles or droplets. Nonetheless, no such synergies were observed for ionic synthetic surfactants. In this case, the interfacial tension values were not as low because of the ineffective interaction between the two groups of surfactants in the interface.

With the exception of the $\mathrm{NaOH}$-containing emulsion, none of the formulations had a beneficial effect on viscosity, for they exhibited higher values than the initial emulsion and more water had to be added to lower the values to the (400 cp) maximum allowed in Spanish standard UNE-104.231. Moreover, viscosity was observed to rise with storage time at high salinity values or in the presence of synthetic surfactants. Furthermore, the emulsions that contained sodium hydroxide exhibited particularly low viscosity and interfacial tension values across the entire range considered, and higher alkalinity values enhanced stability.

\section{ACKNOWLEDGEMENTS}

The cooperation of INTEVEP S.A. is gratefully acknowledged.

\section{BIBLIOGRAFÍA / BIBLIOGRAPHY}

(1) NBE QB-90. Norma Básica de la Edificación "Cubiertas con materiales bituminosos". Madrid (1990).

(2) AENOR, Norma UNE 104-231. "Impermeabilización. Materiales bituminosos y bituminosos modificados. Emulsiones asfálticas". Madrid (1988).

(3) Márquez, G.; Alejandre, F.J.; Bencomo, M.R.: "Effect of asphaltene and resin oils on the viscosity of bituminous petroleum materials to be used as asphalt primers". Mater. Construcc., 281 (2006), pp. 41-49.

(4) The Asphalt Institute. "Materiales asfálticos, mezclas, construcción y calidad". Productos Asfálticos S.A. Madrid (1985).

(5) Nelson, W.L.; Thery, G.; Noriega, D.: Petróleos crudos de Venezuela y otros países. Ed. Ministerio de Minas e Hidrocarburos. Caracas (1959).

(6) Rosen, M.: Surfactant and Interfacial Phenomena. John Wiley \& Sons Pub. New York (1989).

(7) Schick, M.: Nonionic Surfactants, Chapter 5. Marcel Dekker Inc. New York (1996).

(8) Di Lorenzo, M.: Los Surfactantes y sus aplicaciones en la Industria Petrolera, capítulo 3. PDVSA-INTEVEP Ediciones. Caracas (2000).

(9) López, E.: Extracción, caracterización y estudio de las propiedades interfaciales de los ácidos extraídos del bitumen Cerro Negro. PDVSA-INTEVEP Ediciones. Caracas (1998).

(10) Gutiérrez, X.; Rivas, H.: Surfactantes naturales, propiedades interfaciales. INTEVEP Publicaciones. Los Teques (1992).

(11) Campbell, T.: "The role of alkaline chemicals in the recovery of low-gravity crude oils". Journal of Petroleum Technology, 11 (1982), pp. 2510-2516.

(12) Barnes, H.: "Rheology of emulsions, a review". Colloid Surfaces A: Physicochem. Eng. Aspects, 91 (1994), pp. 89-95. 
(13) Becher, P.: Encyclopedy of Emulsion Technology. Marcel Dekker Inc., New York (1983).

(14) Chang, R.: Química. Mac-Graw Hill Ediciones. México D.F. (1992).

(15) Bagchi, P.; Vold, R.: Colloid Interface Science. New York (1970).

(16) Andrade, P.: Notas sobre la formación de emulsiones. Quimitécnica S.A. Pub. Quito (2001).

(17) ISO 13320-1. "Particle Size Analysis-Laser difractions methods". ISO Standards Handbooks. Geneve (1999).

(18) ASTM D-2041. "Standard method test for specific gravity of bituminous mixtures". ASTM Book of Standards. Philadelphia (1995).

(19) Macritchie, F.: Chemistry at Interfaces. Academia Press Inc. London (1990).

(20) Cárdenas, A.; Gutiérrez, X.; Morles, A.; Rivas, H.: Floculación de emulsiones de bitumen en agua. INTEVEP Publicaciones. Los Teques (1997).

(21) Chiweteliu, C.I.; Hornof, V.; Neale, G.: "Interaction of aqueous caustic with acidic oils". Journal of Canadian Petroleum Tecnology, 28 (1989), pp. 71-78.

(22) Layrisse, I.; Rivas, H.; Acevedo, S.: "Isolation and characterization of natural surfactants present in extra heavy crude oils". Journal Dispersion Science Technology, 5 (1984), pp. 1-18. 